JURNAL KACAPURI

JURNAL KEILMUAN TEKNIK SIPIL

Volume 3 Nomor 2 Edisi Desember 2020

\title{
MANAJEMEN RISIKO KONSULTAN PERENCANA KONTRUKSI DI KOTA BALIKPAPAN
}

\author{
${ }^{1}$ Ferdy Kahandanie \\ ${ }^{2}$ Mahfud \\ ${ }^{(1),(2)}$ Dosen Jurusan Teknik Sipil, Politeknik Negeri Balikpapan \\ E-mail : Ferdy.Kahandanie.MT@gmail.com/Hp.08125077866
}

\begin{abstract}
ABSTRAK
Balikpapan sebagai kota penyangga Ibukota Negara (IKN) di Kalimantan Timur Ada beberapa masalah utama yang sering dihadapi oleh para penyelenggara konstruksi yang terkait dengan proyek pembangunan Gedung, baik yang bersifat teknis maupun non teknis. Terlebih dalam perencanaan, umumnya konsultan perencana pada proyek bangunan gedung mendapatkan kontrak untuk merencanakan sejumlah lokasi yang tersebar di suatu wilayah Pemerintahan. Tentu saja dalam melaksanakan perencanaan bangunan gedung tersebut konsultan perencana memiliki risiko. Penelitian ini bertujuan untuk identifikasi risiko pada proyek perencanaan bangunan gedung. Penelitian ini difokuskan di kota Balikpapan. Studi ini dilakukan dengan metode deskriptif kualitatif untuk dapat memberikan suatu deskripsi yang akurat dan sistematik tentang suatu keadaan dan hubungan yang terjadi antar keadaan yang diteliti. Dengan menguji kevalidan dan reliabilitas data. Hasil penelitian ini menunjukan bahwa terdapat beberapa kelompok risiko yang harus dihadapi konsultan konstruksi. Tindakan penanganan risiko perlu dilakukan untuk mengurangi dampak negatif dari risiko risiko yang termasuk dalam risiko dominan (major risk). Dari risiko - risiko dominan (major risk), dilakukan tindakan mengurangi risiko (risk reduction), mengalihkan risiko (risk transfer) dan menghindari risiko (risk avoidance), Keberadaan risiko-risiko yang tidak dapat diterima (unacceptable) harus mendapatkan perhatian khusus. Metode Penelitian Manajemen risiko konsultan perencana kontruksi di kota Balikpapan dilakukan melalui tahapan proses penelitian sebagai berikut: studi pustaka, survey lokasi, pengambilan data survey,wawancara dan kuisioner, tabulasi data, analisis data. Hasil penelitian ini dapat digunakan oleh perusahaan jasa konsultan perencana proyek dan bila ada penelitian serupa dapat menjadi pengembangan inovasi penelitian selanjutnya.
\end{abstract}

Kata Kunci: manajemen Risiko, deskriptif kualitatif, dan Balikpapan

\begin{abstract}
Balikpapan as a buffer city for the State Capital (IKN) in East Kalimantan several main problems are often faced by construction operators related to building construction projects, both technical and non-technical. Especially in planning, in general, planning consultants on building projects get a contract to plan some locations scattered in a government area. Of course, implementing the building planning consultant has risks.
\end{abstract}


JURNAL KACAPURI

JURNAL KEILMUAN TEKNIK SIPIL

Volume 3 Nomor 2 Edisi Desember 2020

This study aims to identify risks in building planning projects. This research is focused on the city of Balikpapan. This study was conducted using a qualitative descriptive method to provide an accurate and systematic description of a situation and the relationship that occurs between the conditions under study. By testing the validity and reliability of the data. The results of this study indicate that several risk groups must be faced by construction consultants. Risk management measures need to be taken to reduce the negative impact of the risks that are included in the dominant risk. Of the dominant risks, actions to reduce risk, transfer risk, and avoid risk, the existence of unacceptable risks must receive special attention. Research Methods Risk management of construction planning consultants in the city of Balikpapan is carried out through the following stages of the research process: literature study, location survey, survey data collection, interviews and questionnaires, data tabulation, data analysis. The results of this research can be used by project planning consulting services companies and if there is similar research it can be the development of further research innovations.

\section{Keywords: risk management, qualitative descriptive, and Balikpapan}

\section{PENDAHULUAN}

Proyek konstruksi adalah suatu upaya untuk mencapai suatu hasil dalam bentuk bangunan atau infrastruktur. Proses yang terjadi pada suatu proyek tidak akan berulang pada proyek lainnya. Hal ini disebabkan oleh kondisi yang mempengaruhi proses suatu proyek satu sama lain, Ervianto, (2004). Dalam pelaksanaannya, proyek konstruksi membutuhkan suatu manajemen. Manajemen proyek mempunyai kewajiban untuk mengkoordinasikan para pihak yang terlibat dalam proyek konstruksi tersebut, sehingga tujuan proyek dapat tercapai dengan baik dan semua pihak secara optimal mendapat hal hal yang menjadi sasaran mereka untuk terlibat dalam proyek tersebut. Risiko-risiko yang terjadi pada proyek ini dihadapi oleh pihak-pihak yang terlibat dalam pelaksanaan proyek yaitu pemilik proyek, kontraktor dan konsultan serta masyarakat yang merasakan gangguan akibat pelaksanaan proyek. Konsultan perencana pada proyek bangunan gedung mendapatkan kontrak untuk merencanakan sejumlah lokasi yang tersebar di suatu wilayah Pemerintahan. Tentu saja dalam melaksanakan perencanaan bangunan gedung tersebut konsultan perencana memiliki resiko. Penelitian ini bertujuan untuk menganalisis resiko pada proyek perencanaan bangunan gedung di Kota balikapapan yang berpengaruh/berdampak langsung kepada Konsultan Perencana.

Maka penelitian ini diharapkan dapat memberikan informasi mengenai resiko yang mungkin timbul dalam pelaksanaan proyek dan dapat memberikan suatu penilaian dan mitigasi terhadap resiko yang telah teridentifikasi terutama resiko yang dominan, sehingga tujuan proyek dapat tercapai. 
JURNAL KACAPURI

JURNAL KEILMUAN TEKNIK SIPIL

Volume 3 Nomor 2 Edisi Desember 2020

\section{Rumusan Masalah}

Permasalahan dalam penelitian ini adalah "Bagaimana Mitigasi Resiko pekerjaan Bangunan Gedung terhadap konsultan perencana bangunan?".

\section{Tujuan Penelitian}

Mendapatkan dan mengetahui kemungkinan risiko yang terjadi dalam pekerjaan Gedung bangunan dan mitigasi resiko terhadap pekerjaan bangunan gedung

\section{TINJAUAN PUSTAKA}

\section{Konsultan Perencana}

Konsultan adalah seorang tenaga profesional yang menyediakan jasa konsultasi (jasa konsultasi) di daerah tertentu keahlian, seperti akuntansi, pajak, lingkungan, biologi, hukum, koperasi dan lain-lain. Perbedaan antara seorang konsultan dengan konsultan ahli biasa bukan karyawan perusahaan penggunalayan (klien), tetapi seseorang yang menjalankan bisnis mereka sendiri atau bekerja di sebuah perusahaan penasehat, serta berurusan dengan berbagai pengguna layan pada satu waktu. Pengertian konsultan perencanaan menurut Ir. Sulistyo Wicaksono, IAI Berdasarkan Kep. Dir. Jen Cipta Karya Dep. PU no. 023/KPT S/CK/1992 : Konsultan perencanaan/Perencanaan adalah perorangan atau badan hukum yang melaksanakan tugas-tugas di bidang perencanaan konstruksi bangunan atau lingkungan perencanaan kerja bersama dengan aksesoris.

\section{Proyek}

Dalam kegiatan sehari hari kita sering kali menyebutkan proyek sebagai suatu pengerjaan atau suatu kegiatan namun dalam buku A Guide to the Project Management Body of Knowledge (PMBOK) disebutkan bahwa proyek adalah pekerjaan temporer yang dikerjakan untuk menciptakan suatu produk atau pelayanan yang memiliki keunikan. Proyek disebut unik karena produk atau layanan yang dihasilkan nantinya memiliki kekhususan tersendiri dibandingkan dengan yang lain. Jadi proyek pada dasarnya adalah suatu kegiatan melaksanakan pekerjaan yang sifatnya temporer untuk menghasilkan produk yang khas.

\section{Manajemen Risiko}

Manajemen risiko menjadi bagian yang tak terpisahkan dari proses yang bertujuan untuk mengidentifikasi potensi risiko yang terkait dengan proyek dan menanggapi risiko tersebut. Manajemen risiko menyatu dengan area manajemen proyek lainnya. Menurut Djojosoedarso (2003) manajemen risiko adalah pelaksanaan fungasi-fungsi manajemen dalam penaggulangan risiko, terutama risiko yang dihadapi oleh organisasi/perusahaan, keluarga dan masyarakat.

Elemen-elemen utama dari proses manajemen risiko, adalah Menetapkan konteks, Mengidentifikasikan risiko, Menganalisa risiko, Mengevaluasi risiko, Menangani risiko, Memantau dan mereview serta Mengkomunikasikan dan berkonsultasi. 
JURNAL KACAPURI

JURNAL KEILMUAN TEKNIK SIPIL

Volume 3 Nomor 2 Edisi Desember 2020

\section{Penilaian Tingkat Penerimaan Risiko}

(Assement of Risk Acceptability)

\begin{tabular}{|c|c|c|c|c|c|}
\hline $\begin{array}{c}\text { Consequen } \\
\text { ces } \\
\text { Likehood }\end{array}$ & $\underset{5}{\text { Catastropic }}$ & $\underset{4}{\operatorname{Critic}}$ & $\underset{3}{\text { Serious }}$ & Marginal & Negigible \\
\hline $\begin{array}{c}\text { Frequent } \\
5\end{array}$ & $\begin{array}{c}\text { Unacceptab } \\
\text { le } \\
(25)\end{array}$ & $\begin{array}{c}\text { Unacoepta } \\
\text { ble } \\
(20)\end{array}$ & $\begin{array}{c}\text { Unacoepta } \\
\text { ble } \\
(15)\end{array}$ & $\begin{array}{c}\text { Undesirabl } \\
\text { e } \\
(10)\end{array}$ & $\begin{array}{l}\text { Undesirable } \\
\text { (5) }\end{array}$ \\
\hline $\begin{array}{c}\text { Probable } \\
4\end{array}$ & $\begin{array}{c}\text { Unacceptab } \\
\text { le } \\
(20)\end{array}$ & $\begin{array}{c}\text { Unaccepta } \\
\text { ble } \\
(16)\end{array}$ & $\begin{array}{c}\text { Undesirabl } \\
e \\
(12)\end{array}$ & $\begin{array}{c}\text { Undesirabl } \\
e \\
(18)\end{array}$ & $\begin{array}{c}\text { Acceptable } \\
\text { (4) }\end{array}$ \\
\hline $\begin{array}{c}\text { Occasional } \\
3\end{array}$ & $\begin{array}{c}\text { Unacceptab } \\
\text { le } \\
(15)\end{array}$ & $\begin{array}{c}\text { Undesirabl } \\
e \\
(12)\end{array}$ & $\begin{array}{c}\text { Undesirabl } \\
\qquad \begin{array}{c}(9)\end{array}\end{array}$ & $\begin{array}{c}\text { Undesirabl } \\
e \\
(6)\end{array}$ & $\begin{array}{c}\text { Acceptable } \\
\text { (3) }\end{array}$ \\
\hline $\begin{array}{c}\text { Remote } \\
2\end{array}$ & $\begin{array}{c}\text { Undesirable } \\
\text { (10) }\end{array}$ & $\begin{array}{c}\text { Undesirabl } \\
\text { e } \\
(8)\end{array}$ & $\begin{array}{c}\text { Undesirabl } \\
e \\
(6)\end{array}$ & $\begin{array}{c}\text { Acceptabl } \\
e \\
{[4]}\end{array}$ & $\begin{array}{c}\text { Negligible } \\
\text { (2) }\end{array}$ \\
\hline${ }_{1}$ Imporable & $\begin{array}{l}\text { Undesirable } \\
\text { (5) }\end{array}$ & $\begin{array}{c}\text { Acceptabl } \\
e \\
(4)\end{array}$ & $\begin{array}{c}\text { Acceptabl } \\
\text { e } \\
(3)\end{array}$ & Negligible & $\begin{array}{c}\text { Negligible } \\
(1)\end{array}$ \\
\hline
\end{tabular}

(Mahadipta,Ngurah Gede Dwi, 2010, Pengembangan dari Godfery, 1996)

Dari Tabel di atas, dapat diuraikan tingkat penerimaan risiko sebagai berikut :

1. Unacceptable, adalah risiko yang tidak dapat diterima dan harus dihilangkan.

2. Undesirable, adalah risiko yang tidak diharapkan dan harus dihindari.

3. Acceptable, adalah risiko yang dapat diterima.

4. Negligible, adalah risiko yang sepenuhnya dapat diterima.

Dari pertimbangan tingkat penerimaan risiko dan nilai dari skala likehood dan consequences, maka skala penerimaan risiko dapat dirumuskan seperti tabel di bawah ini

\begin{tabular}{|l|l|}
\hline & Skala Penerimaan Risiko \\
\hline Unacceptable & $\mathrm{X} \leq 15$ \\
\hline Undesirable & $5 \leq \mathrm{X}<15$ \\
\hline Acceptable & $3 \leq \mathrm{X}<5$ \\
\hline Negligible & $\mathrm{X}<3$ \\
\hline
\end{tabular}

\section{METODE PENELITIAN}

Penelitin ini dilakukan dengan metode deskriptif kualitatif untuk dapat memberikan suatu deskripsi yang akurat dan sistematik tentang suatu keadaan dan hubungan yang terjadi antar keadaan yang diteliti. Adapun langkah - langkah dalam proses penelitian adalah sebagai berikut :

1. Studi literatur, wawancara, pengamatan dan interview dengan berbagai pihak yang terlibat dengan kepentingan penanganan dan pengalaman pribadi yang terkait dengan Perencanaan proyek Konstruksi. Pemangku kepentingan (stakeholder) yang dilibatkan adalah sistem ini adalah staf dan karyawan konsultan perencana.

2. Analisis kebutuhan (need domain), Menguji kevalidan dan reliabilitas data

3. Perancangan model transformasi berdasarkan hasil yang telah dikumpulkan dan dioleh dalam langkah nomor 2 diatas untuk kepentingan berbagai pemangku kepentingan. 
JURNAL KACAPURI

4. Pembangunan model transformasi untuk mendukung proses transfer dan sharing knowledge, khususnya bagi para pemangku kepentingan.

5. Evaluasi dan uji coba model transformasi Korporasi yang telah dikembangkan apakah sudah sesuai dengan requirements yang telah ditetapkan dan apakah sudah mendukung dengan tujuan penelitian yang telah ditetapkan.

\section{Bagan Alir Penelitian}

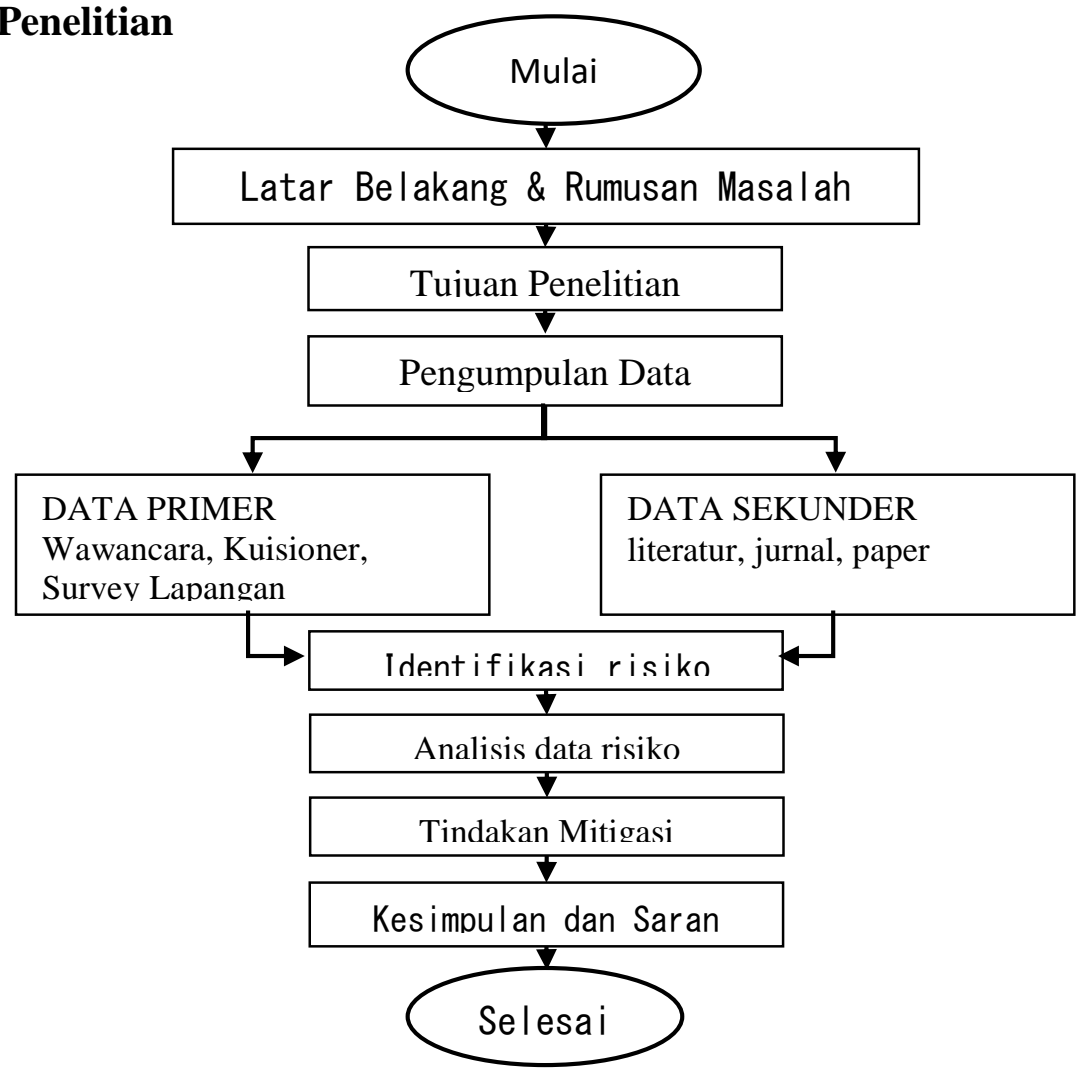

Gambar 1. Diagram Alir Penelitian

\section{HASIL DAN PEMBAHASAN}

Berdasarkan hasil wawancara yang telah dikumpulkan maka didapat data indentifikasi risiko berdasarkan aktivitas dan sumber risiko serta diklasifikasikan menurut sumber risiko yang telah ditentukan (Widerman,1992) dan penelitian sejenis (novatus,2016). Risiko yang teridentifikasi pada proyek konstruksi di Kota Balikpapan sebanyak 33 risiko dan 7 kategori sumber risiko yaitu: Faktor Bahan (material), Faktor Peralatan (equipment), Faktor Keuangan (financing), Faktor Lingkungan dan masyarakat, Faktor Tenaga kerja (man power), Faktor perencanaan, Faktor Manajemen. 
JURNAL KACAPURI

Dalam proyek konstruksi di Kota Balikpapan ini teridentifikasi sumber risiko-risiko berdasarkan aktivitas yang dapat dilihat pada Gambar.

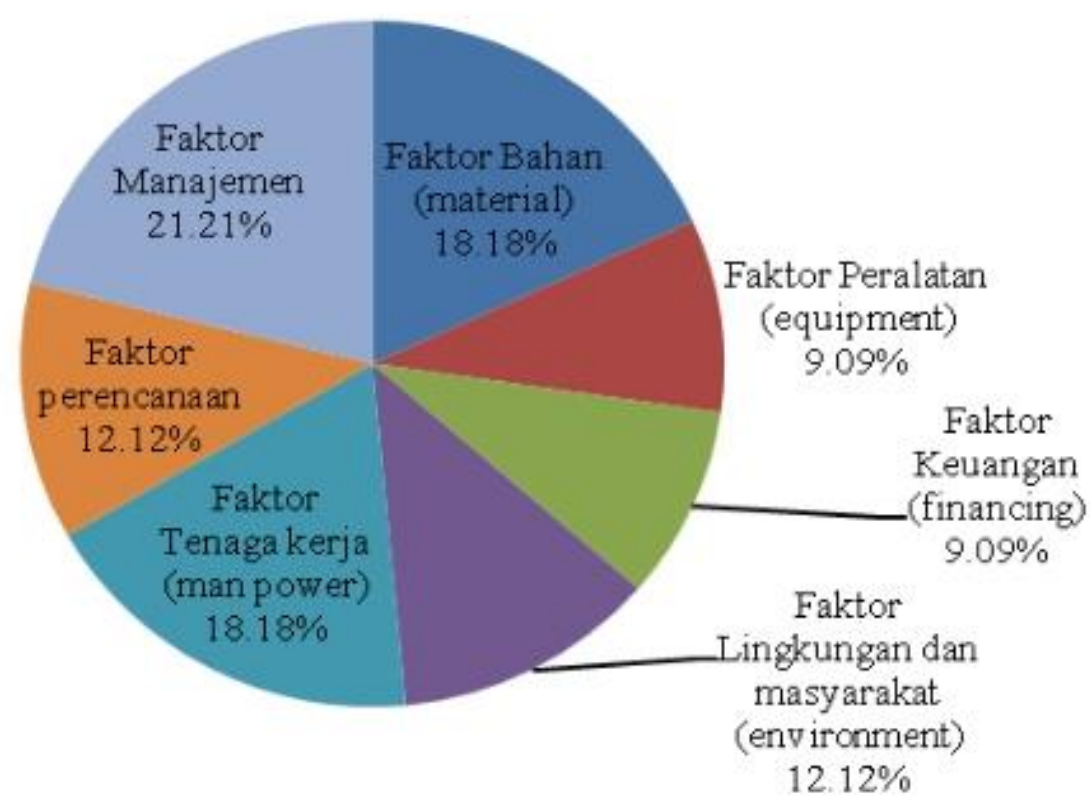

Gambar 2. Jumlah risiko berdasarkan Sumber Risiko

Risiko tenaga kerja muncul 18,8\%, yaitu terbanyak kedua setelah risiko manajemen. Risiko ini timbul karena adanya Kekurangan Tenaga Kerja, Kemampuan tenaga kerja kurangnya Pemahaman spesifikasi pekerjaan yang tidak sama untuk mempercepat penyelesaian proyek yang sedang dilaksanakan.

\section{Uji Reliabilitas}

Uji reliabilitas ini didasarkan pada perhitungan nilai Cronbach's Alpha dengan uji signifikansi pada taraf 0,05. Menurut Priyanto (2008), hasil reliabilitas kurang dari 0,6 adalah kurang baik, sedangkan 0,7 dapat diterima dan di atas 0,8 adalah baik. Berdasarkan perhitungan SPSS for Windows ver. 15, dari item-item pertanyaan dapat diketahui bahwa nilai Cronbach's Alpha adalah 0,922 (di atas 0,7). Dari nilai Cronbach's Alpha tersebut maka dapat disimpulkan bahwa pertanyaan kuesioner tersebut adalah reliable. .

\section{Uji Validitas}

Uji validitas dapat dilakukan dengan dua cara yaitu dengan korelasi Bivariate Pearson (Produk Momen Pearson) dan Corrected Item-Total Correlation (Priyanto, 2008). Uji validitas ini dilakukan dengan membandingkan nilai $r$ pengujian dengan nilai $r$ kritis product moment. Berdasarkan uji 2 sisi dengan taraf signifikansi 0,05 maka diperoleh nilai $r$ kritis untuk 50 responden adalah 0.204 . 
Berdasarkan uji validitas dengan SPSS for Windows ver. 15 dengan teknik analisis Bivariate Pearson, diperoleh nilai koefisien korelasi setiap item pertanyaan nilainya melebihi 0,204 (nilai $r$ kritis dengan signifikansi $(0,05)$ ) maka dapat disimpulkan bahwa item-item pertanyaan dalam kuesioner berkorelasi signifikan dengan skor total sehingga dapat disimpulkan bahwa itemitem tersebut valid.

\section{Jawaban Responden Terhadap Kemungkinan (Likelihood)}

Hasil jawaban responden mengenai kemungkinan (likelihood) risiko sesuai dengan skala penilaian. Representasi jawaban responden terwakili oleh nilai modusnya, Dari modus jawaban responden seperti Tabel 5.3 dapat disimpulkan bahwa
1. Frekuensi skala 1 (sangat jarang)
$: 7$
$: 15$
$(21,21 \%)$
2. Frekuensi skala 2 (jarang)
$: 6$
$(45,45 \%)$
3. Frekuensi skala 3 (kadang-kadang)
$: 4$
4. Frekuensi skala 4 (sering)
$: 1$

Berdasarkan data di atas dapat dilihat bahwa frekuensi terjadinya risiko pada skala 2 (jarang) paling banyak muncul.

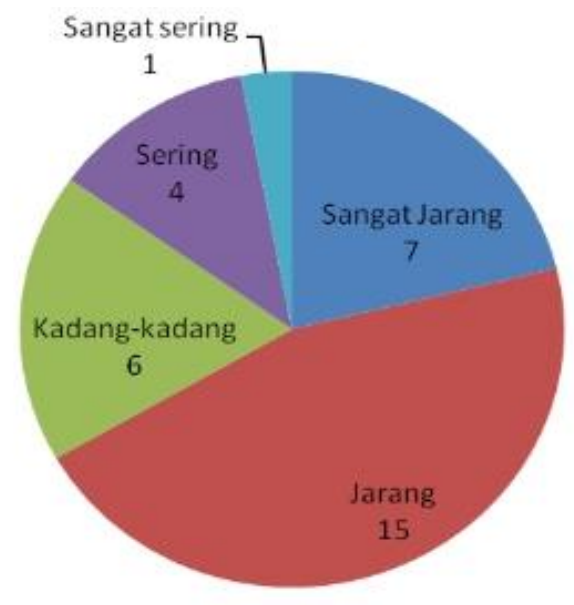

\section{Gambar 3. Frekuensi Kemungkinan (likelihood) Risiko}

Berdasarkan data di atas bahwa jawaban responden terhadap kemungkinan terjadinya risiko cenderung pada frekuensi skala 2 (jarang). Hal ini menunjukkan bahwa risikorisiko yang teridentifikasi adalah jarang terjadi pada tahap pelaksanaan kegiatan.

\section{Jawaban Responden Terhadap Pengaruh (Consequences)}

Hasil jawaban responden mengenai konsekuensi (consequences) risiko sesuai dengan skala penilaian. Representasi jawaban responden terwakili oleh nilai modusnya. Dari modus jawaban responden dapat disimpulkan bahwa

1. Konsekuensi skala 1 (sangat kecil) : $0(0 \%)$

2. Konsekuensi skala 2 (kecil) : $3(9,09 \%)$

3. Konsekuensi skala 3 (sedang) : $13(39,39 \%)$ 
4. Konsekuensi skala 4 (besar)

5. Konsekuensi skala 5 (sangat besar)
$: 17(51,52 \%)$

: $0(0 \%)$

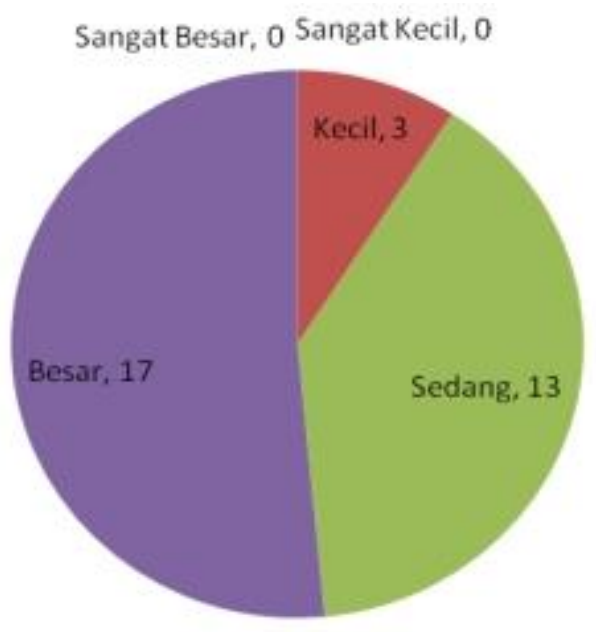

Gambar 4. Frekuensi penilaian responden terhadap Pengaruh (Consequences) terjadinya risiko.

Berdasarkan data di atas bahwa jawaban responden terhadap pengaruh terjadinya risiko paling banyak pada frekuensi skala 4 (besar). Hal ini menunjukkan bahwa risiko yang teridentifikasi memberikan pengaruh besar terhadap proyek. Untuk skala 1 (sangat kecil) dan 5 (sangat besar), responden berpendapat tidak ada risiko yang memiliki pengaruh sangat kecil dan sangat besar.

\section{Penilaian Responden}

Penilaian responden terhadap tingkat penerimaan risiko pada proyek konstruksi di Kota Balikpapan dapat diuraikan sebagai berikut:

1. Unacceptable (tidak dapat diterima).

2. Undesirable (tidak diharapkan).

3. Acceptable (dapat diterima).

4. Negligible (dapat diabaikan).

Penilaian risiko dilakukan dengan mengalikan kemungkinan (likelihood) dan pengaruh (consequences) seperti yang terlihat pada tabel diatas. Berdasarkan hasil perkalian tersebut diperoleh nilai risiko untuk dapat menentukan tingkat penerimaan risiko (acceptability of risk). Hasil penerimaan risiko dapat dijelaskan sebagai berikut:

1. Unacceptable (tidak dapat diterima)

2. Undesirable (tidak diharapkan)

$: 4$ risiko

3. Acceptable (dapat diterima)

: 21 risiko

4. Negligible (dapat diabaikan)

: 6 risiko

: 2 risiko 
JURNAL KACAPURI

JURNAL KEILMUAN TEKNIK SIPIL

Volume 3 Nomor 2 Edisi Desember 2020

\section{Risiko-risiko Dominan (Major Risk)}

Risiko-risiko yang bersifat dominan (major risk) adalah risiko-risiko yang termasuk kategori unacceptable (risiko yang tidak dapat diterima) dan risiko-risiko yang termasuk kategori undesirable (risiko yang tidah diharapkan).

Risiko ini merupakan risiko dengan risk acceptability nilai perkalian likehood dan consequences sama dengan atau di atas 5. Keberadaan risiko-risiko dominan (major risk) akan berpengaruh besar pada proyek konstruksi di Kota Balikpapan.

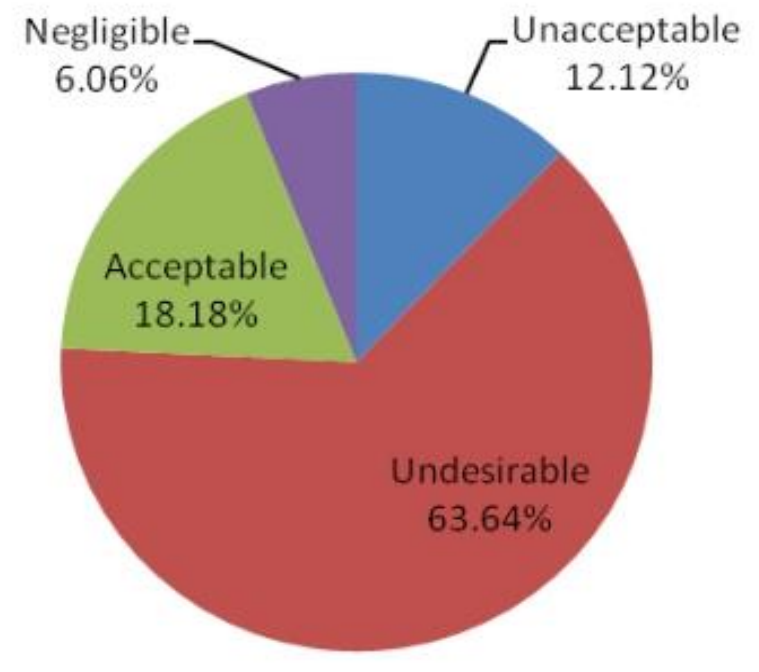

Gambar 5. Keberadaan risiko-risiko dominan (major risk) akan berpengaruh besar pada proyek konstruksi di Kota Balikpapan.

Dalam tingkat penerimaan risiko dapat dilihat bahwa risiko dominan besarnya 63,64\%. Presentase risiko-risiko dominan yang cukup besar menunjukkan banyak risiko-risiko yang tidak diharapkan dalam proyek. Risiko-risiko dominan ini harus mendapatkan perhatian khusus dari pihak-pihak berkompeten yang memiliki tanggung jawab terhadap terjadinya risiko untuk dapat dilakukan tindakan mitigasi agar dapat mengurangi dampak negatif yang ditimbulkan dari risiko yang terjadi.

\section{Tingkat Penerimaan Risiko (Risk Acceptability)}

Tingkat penerimaan risiko di atas dapat dijelaskan persentase tingkat penerimaan risiko adalah sebagai berikut

1. Unacceptable (tidak dapat diterima)

$$
: 4 \text { risiko }(12,12 \%)
$$

2. Undesirable (tidak diharapkan) $: 21$ risiko $(63,64 \%)$

3. Acceptable (dapat diterima) : 6 risiko $(18,18 \%)$

4. Negligible (dapat diabaikan) $\quad: 2$ risiko $(6,06 \%)$

Dari 33 Risiko yang teridentifikasi, dapat dilihat berdasarkan hasil penelitian diatas bahwa 25 risiko tersebut $(75,76 \%)$ adalah major risk. Jadi bisa dikatakan bahwa proyek 
JURNAL KACAPURI

JURNAL KEILMUAN TEKNIK SIPIL

Volume 3 Nomor 2 Edisi Desember 2020

konstruksi di Kota Balikpapanadalah proyek-proyek pembangunan yang berisiko tinggi (high risk) karena lebih dari setengah risiko yang teridentifikasi merupakan risiko dominan sehingga harus mendapatkan perhatian khusus.

\section{Distribusi Penerimaan Risiko untuk Setiap Sumber Risiko}

Risiko yang termasuk kategori tidak dapat diterima (unacceptable) sebanyak 4 risiko $(12,12 \%)$. Risiko dengan penerimaan risiko yang tinggi adalah kendala dalam pemenuhan material dan keterlambatan material. Risiko yang termasuk kategori tidak diharapkan (undesirable) sebanyak 21 risiko $(63,64 \%)$. Risiko yang dapat diterima (acceptable) sebanyak 6 risiko $(18,18 \%$ ) dan risiko yang dapat diabaikan (negligible) 2 risiko sebesar $6,06 \%$.

\section{Risiko dengan Kategori Unacceptable (tidak dapat diterima)}

Berdasarkan sumbernya, risiko yang termasuk kategori tidak dapat diterima (Unacceptable) sebanyak 4 risiko dapat diuraikan sebagai berikut
1. Risiko Material
: 2 risiko
2. Risiko peralatan
: 1 risiko
3. Risiko Manajeman
: 1 risiko

Dapat dilihat bahwa risiko yang tidak dapat diterima paling banyak berasal dari risiko material. Hal ini menunjukkan bahwa risiko proyek memiliki pengaruh yang sangat besar apabila tidak ditangani dengan penuh perhatian.

\section{Risiko dengan Kategori Undesirable}

Berdasarkan sumbernya, risiko yang termasuk kategori tidak dapat diharapkan (undesirable) sebanyak 21 risiko dapat diuraikan sebagai berikut

1. risiko Bahan (material)

2. risiko Peralatan (equipment)

3. risiko Keuangan (financing)

4. risiko Lingkungan dan masyarakat (environment)

5. risiko Tenaga kerja (man power)

6. risiko perencanaan

7. risiko Manajemen dapat dilihat bahwa risiko yang tidak diharapkan paling banyak muncul pada risiko proyek yaitu sebanyak 21 risiko. Dalam tahap pelaksanaan proyek konstruksi di Kota Balikpapan, risiko-risiko proyek lapangan menjadi hal yang harus diperhatikan karena menyangkut kelancaran proyek, sehingga penanganan yang matang sangat diperlukan untuk menangani risiko-risiko proyek yang tidak diharapkan tersebut. Hal ini disebabkan oleh tingginya frekuensi terjadinya risiko tersebut dan besarnya dampak negatif yang ditimbulkan dari risiko ini bila tidak ditangani.

\section{Mitigasi Risiko (Risk Mitigation)}

Keberadaan risiko-risiko dominan (major risk) akan memberikan pengaruh yang sangat besar pada proyek konstruksi di Kota Balikpapan. Risiko-risiko yang termasuk dalam kategori risiko yang tidak dapat diterima (unacceptable) dan risiko yang masuk dalam kategori tidak diharapkan (undesirable) memerlukan adanya tindakan mitigasi 
JURNAL KACAPURI

JURNAL KEILMUAN TEKNIK SIPIL

Volume 3 Nomor 2 Edisi Desember 2020

untuk mengurangi atau meminimalkan risko dan dampak yang ditimbulkan. Mitigasi risiko dapat dilakukan dengan mengurangi risiko (risk reduction), menahan risiko (risk retention), mengalihkan risiko (risk transfer) dan menghindari risiko (risk avoidance). Risiko-risiko yang termasuk kategori dapat diterima (acceptable) dan kategori dapat diabaikan (negligible) tidak memerlukan adanya mitigasi karena risiko-risiko tersebut dapat ditahan (risk retention).

\section{Mitigasi Risiko Unacceptable}

Tindakan mitigasi untuk risiko-risiko yang termasuk dalam kategori tidak dapat diterima (unacceptable) dapat dilakukan penanganan resiko sesuai dengan hasil wawancara yang dilakukan dengan pihak yang berkompeten adalah Addedum kontrak, Asuransi, Menghindari sanksi

\section{Mitigasi Risiko Undesirable}

Tindakan mitigasi untuk risiko-risiko yang termasuk dalam kategori tidak dapat diterima (undesirable) dapat dilakukan sesuai dengan hasil wawancara yang dilakukan dengan pihak yang berkompeten tentang cara bagimana mengelola risiko agar dapat mengurangi dampak negatif yang ditimbulkan, dijelaskan pada. Menyiapkan gudang, Sewa alat pihak ketiga, safety control dan pengawasan peralatan, asuransi, Pengamanan pihak ketiga, Sertifikasi perusahaan, Tenaga ahli.

\section{PENUTUP}

Penilaian risiko yang dilakukan meliputi : Identifikasi risiko, memahami kebutuhan atau mempertimbangkan risiko, menganalisis dampak dari risiko tersebut/evaluasi risiko, menetapkan siapa yang bertanggung jawab terhadap risiko tertentu (alokasi risiko). Melakukan tindakan penanganan yang dilakukan terhadap risiko yang mungkin terjadi (respon risiko) dengan cara : menahan risiko (risk retention), mengurangi risiko (risk reduction), mengalihkan risiko (risk transfer), menghindari risiko (risk avoidance).

1. Identifikasi risiko, pada pelaksanaan proyek konstruksi di Kota Balikpapan teridentifikasi 33 risiko berdasarkan aktivitas pada tahap pelaksanaan proyek.

2. Risiko dominan adalah pada proyek konstruksi yang termasuk kategori dominan (major risk) sebanyak 25 risiko yang terdiri dari 4 risiko yang tidak dapat diterima (unacceptable) dan kategori tidak diharapkan (undesirable) sebanyak 21 risiko dengan risiko terbanyak berasal dari risiko manajemen.

3. Mitigasi risiko adalah tindakan yang dilakukan untuk mengurangi dampak negatif dari risiko-risiko yang termasuk dalam kategori risiko dominan (major risk). Untuk risiko yang termasuk kategori tidak dapat diterima (unacceptable) ada 4 risiko, dilakukan 4 tindakan mitigasi yaitu dengan melakukan pembuatan schedule yang lebih teliti. 
JURNAL KACAPURI

JURNAL KEILMUAN TEKNIK SIPIL

Volume 3 Nomor 2 Edisi Desember 2020

\section{DAFTAR PUSTAKA}

1. A Guide to The Management Body of Knowledge (PMBOK Guide) Fifth Edition, 2013, Publisher by: Project Management Institute,Inc. Pennsylvania 19073-3299 USA

2. Anonim, 2009, Konstruksi Manajemen Risiko, Konstruksi Bahasa Inggris untuk Teknik Sipil Rumah ASTM Buku Teknik Sipil

3. Arie, Julius H. , Artama, I Putu W., 2008, analisis risiko Terhadap Waktu Penyelesaian Proyek pada Pembangunan Perumahan di Surabaya, Prosiding Seminar Nasional Manajemen Teknologi VIII Program Studi MMT-ITS, Surabaya

4. Asiyanto, 2005, Manajemen Produksi untuk jasa konstruksi, Pradnya Paramita, Jakarta

5. COSO (The Committee of Sponsoring Organizations of the Treadway Commission), 2004, Enterprise Risk Management : Integrated Framework, download tanggal 15 Juni 2009

6. Darmawi, H. 2006. Manajemen Risiko. Cetakan kesepuluh. Jakarta : Bumi Aksara.

7. Darmawi, H.,2006, Manajemen risiko, Bumi Aksara, Jakarta, Indonesia

8. Eriyanto. 2007. Teknik Sampling Analisis Opini Public. Jogjakarta ; Pelangi Aksara.

9. Godfrey, P.S., Sir William Halcrow and Partners Ltd. 1996. Control of Risk A Guide to Systematic Management Of Risk from Construction. Wesminster London: Construction Industry Research and Information Association (CIRIA).Crouhy M, Galai D, Mark R. 2001. Risk Management. USA: McGraw Hill.

10. Mahadipta, N. G. 2010. "Analisis Risiko Pada Proyek Pembangunan Sentral Parkir di Pasar Badung" (tesis).Badung; Universitas Udayana.

11. Menteri Hukum dan Hak asasi Manusia,2017.'Undang undang tentang jasa konstruksi No. 02 tahun 2017'. Jakarta : Kementrian Hukum dan HAM.

12. Smith N.J., 1999, "Managing Risk in Construction Projects"., London, Blackwell Science

13. Soeharto I. 1999. Manajemen Proyek : dari Konseptual sampai Operasional. Jakarta: Erlangga.

14. Stoneburner G, Goguen A, Feringa A. 2001. Risk Management Guide for Information Technology System. National Institute of Standart and Technology. US Departement of Commerce.

15. Sugiyono. 2004. Metode Penelitian Kuantitatif, Kualitatif dan R\&D. Bandung: Alfabeta. 